\title{
Premises for the development of digital services in Russian rural areas in search of sustainability
}

\author{
Igor Aleksandrov ${ }^{1 *}$, Marina Fedorova ${ }^{2}$, and Aleksey Parshukov ${ }^{1}$ \\ ${ }^{1}$ Peter the Great St.Petersburg Polytechnic University, Polytechnicheskaya 29, 195251, St. \\ Petersburg, Russia \\ ${ }^{2}$ Petrozavodsk State University, Lenina 33, 185910, Petrozavodsk, Russia
}

\begin{abstract}
The objective of the paper is to analyses the premises of the development of e-commerce and other various online services possible to be provided by rural people. As far as our former researches show that rural community is concerned about its environment and do its best to preserve nature and cultural heritage, but lack of resources make obstacles to stop some natural problems. Moreover, rural people suffer from unemployment, so their priority is to find a job and means for life. We see that new job opportunities could solve the problem of unemployment and boost new activities to take care of their homeland. So we analyze the level of Internet penetration to the countryside and how it influences on new opportunities for employment in the countryside.
\end{abstract}

\section{Introduction}

In a view of plethora of problems rural people have to solve to provide themselves decent level of life, unemployment, is the first one which causes outmigration and degradation of rural people. At the present time, countryside living or tourism to the countryside gains its popularity. But the problem is that Russian countryside is not ready to host guests or tourists and even its locals do not possess sufficient social infrastructure and, what is very important in such circumstances, ecological environment. Despite the fact that rural community is really concerned about its environment the problems of unemployment are in priority and they do not leave nor time neither resources to take care about nature or cultural heritage adequately.

At the same time postindustrial economy which brings services at center stage, and digital economy which moves the process of selling and promoting services and even plenty of various or new sorts of services to digital space, both of them give new opportunities for inhabitants of less favoured territories, notably, new opportunities in employment or starting entrepreneurial activity.

\footnotetext{
* Corresponding author: a7830298@gmail.com
} 


\section{Literature review}

The number of studies about the Internet development influence on the development of different on-line services in rural areas is not sufficient at the present time. As we see, the development of on-line service is very important at the time of digital era, especially for less-favored territories in Russia suffering from lack of other resources to earn money. That is why we argue that digital economy is strongly associated with postindustrial economy where services as education, tourism, health care, finances, etc. play the major role.

At the same time in the research of A. H. F. Li [1] we see the example of the development of Taobao villages with the deployment of Internet and government support which was essential to provide broadband Internet. Another example of entrepreneurship development in less favoured territories we find in the research of N. Sukasame et al. [2].

For example, according to the research of Bertschek I. et al. [3] companies of service industry, notably, the companies the companies who are in need of executives possessing special skills are the main users of broadband Internet spread.

According to the research of Boland M. and Ivus O. [4] the deployment of broadband Internet influence positively on the development of service industry, particularly, in IT sphere in rural territories. But the it has no influence on the manufacturing of industrial goods. The researches also concluded that the deployment of broadband Internet influence positively on the development of service industry due to former development of service industry in cities. The reason is considered to be in the easiness to move the business of service industry from one place to another.

The research of Kolko J. [5] shows that IT executives depend on Internet development most of all. Such service industries as management of big companies, different kinds of research services, technical and information services also showed themselves to depend on the Internet deployment at territories. There is almost no connection between Internet development and education services, health care and social service, art, entertainment and recreation services. It should be mentioned that the researcher forecasted that in future the causation can be changed. That is why and taking into account the situation caused by the spread of coronavirus we make the hypothesis that at the present time the deployment of Internet can favor the development of education, entertainment and recreational services.

\section{Materials and methods}

For the research of the premises of Internet deployment influence on the development of services industry in Russian countryside the statistical data of various types of communication among was analysed. The next step was to analyse the share of urban and rural population uses Internet and the major objectives to use Internet. The statistic data on the share of the most popular communication services was taken and processed from the Ministry of Digital Development, Communications and Mass Media of the Russian Federation.

\section{Research}

According to the data of incomes from communication services in Russia for the period from 2009 to 2019 (Figure 1) we can analyze which type of communication services is in demand most of all at the present time.

We can see (Figure 1) that the largest amount of incomes the Ministry of Digital Development, Communications and Mass Media of the Russian Federation gets from such types of services as mobile communication and transmitting different types of documents. 
But despite high initial rates the incomes from mobile communication have been falling from 2013. And in 2017 we can see that those incomes are less than the incomes from services of documents transmitting. We also see that incomes for the services of radio, broadcasting, TV, satellite, postal services and services for the use of radio spectrum and radio electronic devices are much lesser than leader services and do not exceed the 100000 millions of rubles.

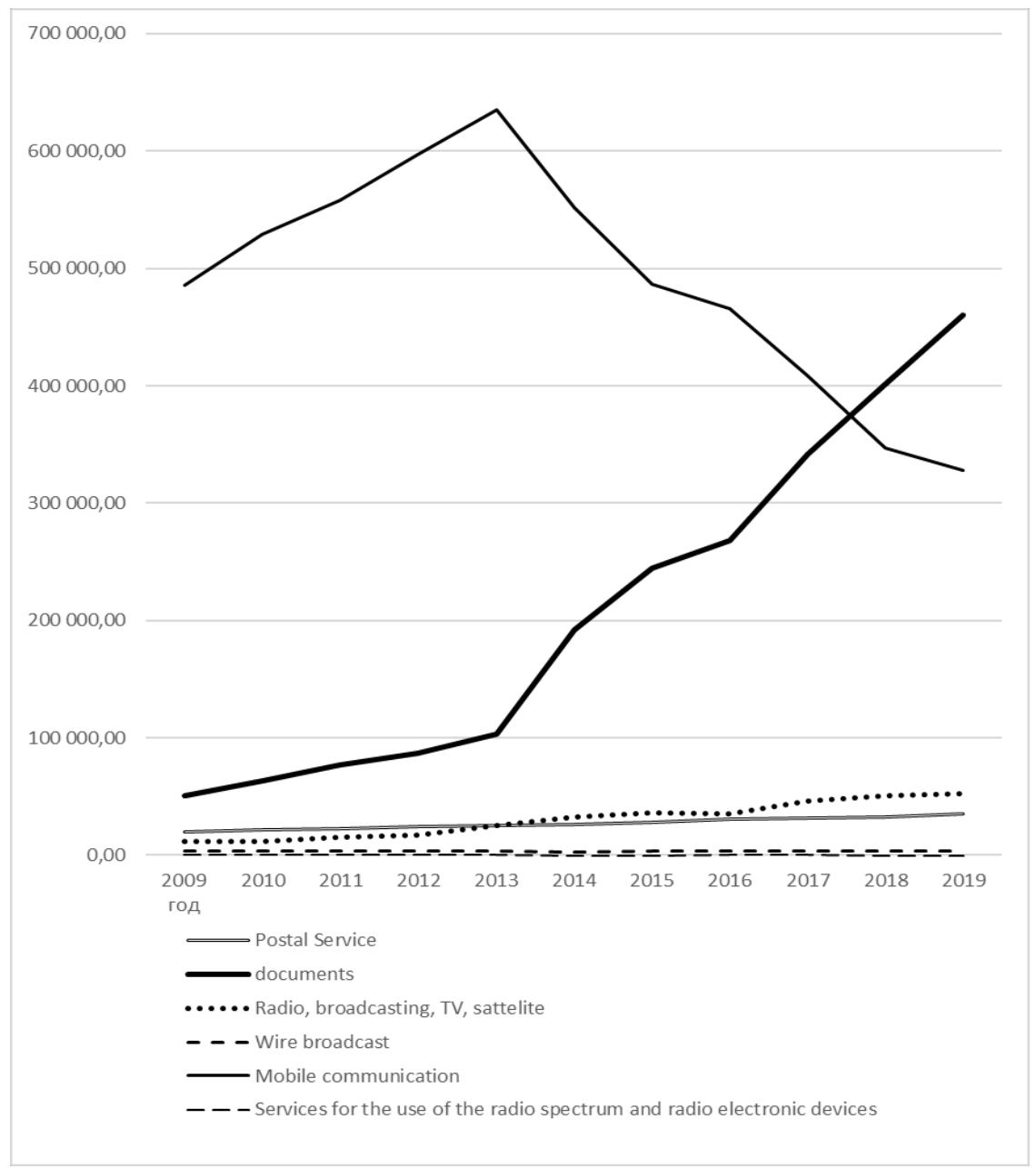

Fig. 1. Incomes from communication services in Russia for the period from 2009 to 2019, millions of rubles (according to data of the Ministry of Digital Development, Communications and Mass Media of the Russian Federation [6]).

The more detailed analysis of incomes from different types of communications shows that there are incomes which are not high enough but show positive tendency such as the services of radio, broadcasting, TV, satellite, postal services (Figure 2).

It should be mentioned that if in 2016 the incomes from radio, broadcasting, TV and satellite became lower and then rose sharply, the incomes for the postal services at the same year continued its positive growth and declined just a bit the next year only. Those incomes grow that also proves the hypothesis that the amount of Internet connection grow also, and the coverage of Internet and other types of communications develops (Figure 1,2). That is 
very important for less favored territories. But we cannot say the same about mobiles communications, because of the difficulties of customer base building.

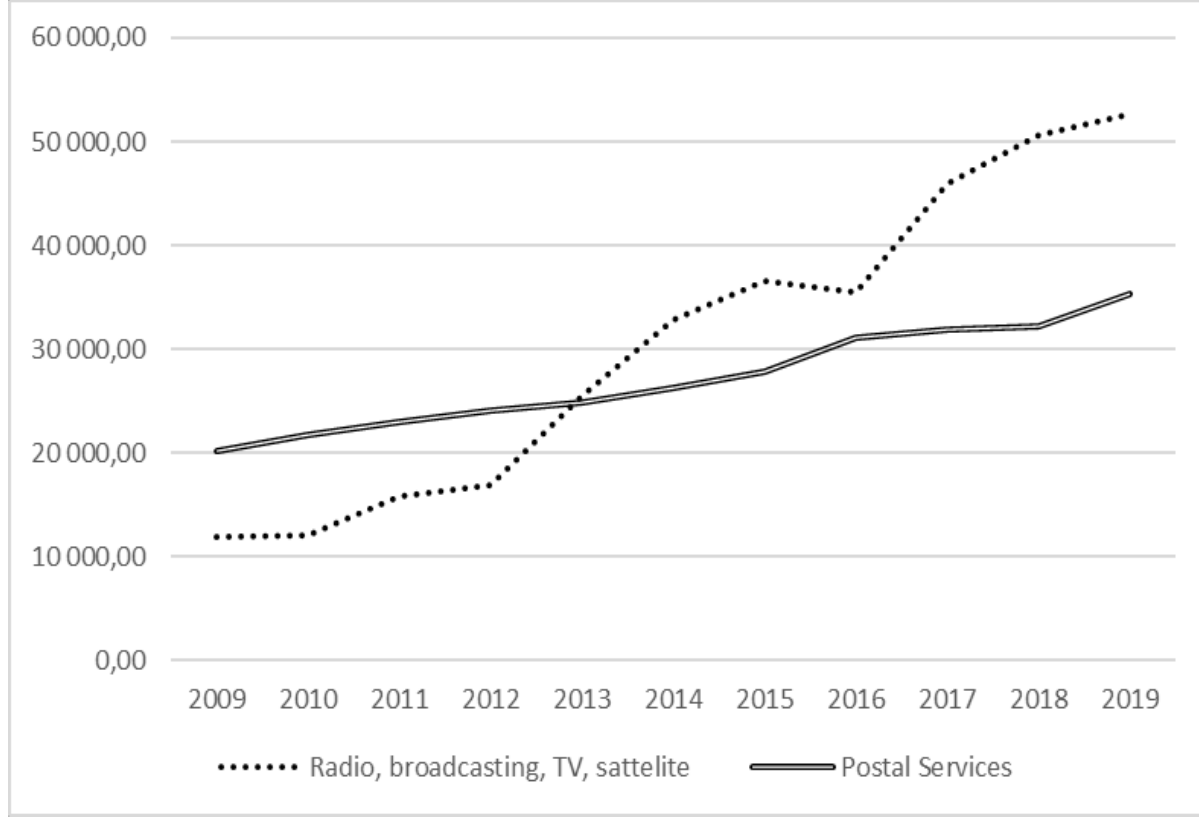

Fig. 2. Incomes from communication services in Russia for the period from 2009 to 2019, millions of rubles (according to the data of the Ministry of Digital Development, Communications and Mass Media of the Russian Federation [6]).

As to incomes for the wire services and of radio, broadcasting, TV and satellite services, they are much more less than incomes from documents' transmitting (Figure 1). That is why we can argue that the demand on those types of services is highest and the most dynamic at the present time. So we can make another hypothesis that consuming various types of digital content and services of documentary communications is in high demand, as far as the Internet today is a kind of space where a service provider and a service consumer, firstly, find one another, and secondly, very often there is a plethora of services which are consumed also in the Internet. And one of the explanations of such reality are contemporary conditions of digital economy.

According to the Table 1 we also can conclude that the share of rural population using Internet grows more dynamically than urban population. It can be explained by the fact that the access to the Internet was provided earlier in cities that in the countryside. Unfortunately, there are still rural territories where we cannot possess Internet access. Another point is that the migration from the countryside to cities still takes place and remain the problem, the population of the countryside continues to decline. That is why the data about the growth of rural population using Internet are considered to be positive even from the point to eliminate digital inequality which place an important role in the development of uniform digital environment in the digital economy.

According to statistical data the share of population using Internet has been rising every year (Table 2). The most important is that companies and individuals use Internet each year more often to interact and make business transactions (Table 2). So supporting the opinion that increasing of self-employment of local population is one of the most perspective ways to lessen the unemployment in the countryside [10], we also suppose that in the new conditions of the growth of digital transactions and gradual penetration of the Internet to the 
countryside, the self-employment can be improved with the help of Internet, firstly, providing different types of services, and secondly, using Internet to promote and sell services.

Table 1. Population using Internet, \% from the whole population [7-9]).

\begin{tabular}{|l|c|c|c|c|c|}
\hline & 2014 & 2015 & 2016 & 2017 & 2018 \\
\hline City & 78.7 & 81.7 & 84.3 & 86.8 & 83.4 \\
\hline Countryside & 60.4 & 65.5 & 70.3 & 74.3 & 80.3 \\
\hline
\end{tabular}

Table 2. Share of population and companies using Internet for private and entrepreneurial purposes, $\%[7-9])$.

\begin{tabular}{|l|l|l|l|l|l|l|}
\hline & 2013 & 2014 & 2015 & 2016 & 2017 & 2018 \\
\hline $\begin{array}{l}\text { Share of population using Internet } \\
\text { everyday, among the whole share of } \\
\text { population \% }\end{array}$ & 48.1 & 51.6 & 55.1 & 57.7 & 60.6 & 68.8 \\
\hline $\begin{array}{l}\text { Share of companies using Internet to } \\
\text { interact with suppliers, among the } \\
\text { whole share of companies, \% }\end{array}$ & 67.1 & 66.1 & 66.4 & 66.7 & 67.7 & 69.8 \\
\hline $\begin{array}{l}\text { Share of companies using Internet to } \\
\text { interact with customers, among the } \\
\text { whole share of companies, \% }\end{array}$ & 47.5 & 46.2 & 46.8 & 48.2 & 49.0 & 51.7 \\
\hline
\end{tabular}

\section{Discussion}

At the present time there are not too many researches in the sphere of Internet use to develop entrepreneurship in rural territory. For example, Papandrea F. and Wade M. [11] implemented an interview of small and medium rural entrepreneurs of Australia. The researches concluded that all of interviewed entrepreneurs use their web-sites to promote and sell their products. Only one entrepreneur answered that the web-site is useless in his or her business. It should be added that the usefulness of web-sites is mitigated by the popularity of social networks. So some entrepreneurs withdraw maintain web-sites in favour of social networks. That is should also be taken in mind undertaking an entrepreneurial activity with the help of Internet.

One of the most perspective niches for the countryside we consider to be e-commerce [12]. Moreover, the development of service industry in the Internet in rural area can take different images [13] taking into account cultural and natural resources of a territory and its human capital. Development of e-commerce in rural territory could boost the development of entrepreneurial activity of rural local people and increase the employment. In the researches of Markley D. M. et al. [14] and Zapata S.D. et al. [15] we see, that rural entrepreneurs use the Internet to promote their products and services. They also use or even develop special platforms and marketplaces where rural entrepreneurs would be able to sell their products and services. It advances the process of sells to another, higher, level, which corresponds the reality of digital economy to great extent, but do not answer the calls of postindustrial economy because the share of service, notably digital services, is still insufficient.

In the researches of Fedorova M. Yu. and Aleksandrov I.N. [16] we see that rural people are interested in additional source of income and the majority of local rural people prefer to earn with the help of new options caused by digital era. But at the present time locals do not dispose comprehensive information and do not possess needed skills to start entrepreneurial activity in this sphere. 
That is why considering the growth of incomes from transmitting different types of documents we want to analyze the objectives the population uses Internet (Table 3). As we see the consumption of various types of content in the Internet grows each year, as also the diversity and variety of the content, which is generalized in the statistical data and was chosen to be analyzed to demonstrate digital services in demand nowadays.

Table 3. Objectives to use Internet by the population, \% from the whole population using Internet [79]).

\begin{tabular}{|l|c|c|c|c|c|}
\hline & 2014 & 2015 & 2016 & 2017 & 2018 \\
\hline $\begin{array}{l}\text { Downloading and watching films, graphics, music; } \\
\text { listening to music or radio }\end{array}$ & 49.5 & 49.6 & 51.4 & & 49.2 \\
\hline Search for information about goods and services & 37.0 & 39.6 & 43.8 & 51.7 & 54.1 \\
\hline $\begin{array}{l}\text { Reading and downloading online newspapers, } \\
\text { journals and e-books }\end{array}$ & 19.2 & 21.1 & 22.1 & 25.0 & 22.9 \\
\hline Sells / buying goods and services & 14.5 & 15.3 & 17.5 & 18.9 & 24.9 \\
\hline $\begin{array}{l}\text { Search for information about education, courses, } \\
\text { trainings, etc.. }\end{array}$ & 9.4 & 8.8 & 9.0 & 11.7 & 8.8 \\
\hline Distance learning & 3.0 & 2.9 & 2.7 & 3.6 & 3.1 \\
\hline
\end{tabular}

\section{Conclusion}

That is why we argue that as far as the services of documents transmitting are in the highest demand today (Figure 1), which can be compared only with the demand on the services of mobile communication at its very beginning, there are new options for individuals, notably for those living in less favoured territories, to start their own entrepreneurial activity, or to find a job. The point is that because of the conditions digital economy and postindustrial economy, the most favourable space where new entrepreneurial activity should take place is Internet and various digital services are the most preferable services to be sold and implemented. Such kind of activity does not make an individual live in a city but allow him or her to opt to more appropriate and ecofriendly territory which very often is the countryside. As the examples of digital services there can be content like video, audio or text messages for wide range of audience to meet educational, entertainment or business needs of consumers. Even services to find any good or product, or information, making a deal and deliver it to its consumer if we are talking about e-commerce also take place. However the possibilities are limited by low entrepreneurial literacy of rural people and the literacy of searching a job or providing services or entrepreneurial activity in the Internet which is proved in our former researches. That is why we suppose that despite of positive premises the industry of services to be developed in digital sphere and using digital tools to promote and sell services from and inside rural territories there is also the range of factors preventing its development.

\section{References}

1. A. H. F. Li, E-commerce and Taobao Villages, Ch. Persp. 3, 57-62, (2017) DOI: https://doi.org/10.4000/chinaperspectives.7423

2. N. Sukasame, T. C. Sebora, A. Mohedano-Suanes, E-commerce entrepreneurship as a national priority: the case of Thailand, Ser. Ind. J. 28, 7, 989-1001 (2008) DOI: 10.1080/02642060701861357

3. I. Bertschek, W. Briglauer, K. Hüschelrath, B. Kauf, T. Niebel, The Economic Impacts of Telecommunications Networks and Broadband Internet, A Survey.: Centre for 
Europeun Economic Research, Discussion Paper 16-056, 51 (2016) URL: https://euagenda.eu/upload/publications/untitled-88625-ea.pdf

4. M. Boland, O. Ivus, The Employment and Wage Impact of Broadband Deployment in Canada, Canadian Journal of Economics 48, 5, 1803-30 (2015) DOI: 10.1111/caje. 12180

5. J. Kolko, Broadband and local growth, Journal of Urban Economics 71, 1, 100-113 (2011) URL: 10.1016/j.jue.2011.07.004

6. Ministry of Digital Development, Communications and Mass Media of the Russian Federation URL: https://digital.gov.ru/ru/

7. K. E. Lajkam, G.I. Abdrahmanova, L.M. Gohberg, O. Yu. Dudorova et al., Information Society in the Russian Federation (Moskva : NIU VSHE, 2017)

8. K. E. Lajkam, G.I. Abdrahmanova, L.M. Gohberg, O. Yu. Dudorova et al., Information Society in the Russian Federation (Moskva : NIU VSHE, 2019)

9. K. E. Lajkam, G.I. Abdrahmanova, L.M. Gohberg, O. Yu. Dudorova et al., Information Society in the Russian Federation (Moskva : NIU VSHE, 2018)

10. A.E. Ilin, D.A. Savin, A.M. Konorev, Rural unemployment: state and ways to reduce, Vestnik of Kursk State Agricultural Academy 47-9, 3 (2012)

11. F. Papandrea, M. Wade, E-commerce in Rural Areas - Case studies Rural Industries Research and Development Corporation (2000)

12. V. V. Makarov, Yu. O. Kolotov, Economic analisis: theory and practice, E-commerce development 155, 60-4, 26 (2009)

13. I. Aleksandrov, A. Burmistrov, O. Rasskazova, M. Yu. Fedorova, Self-development of rural areas under digital economy conditions as exemplified by Northwestern Federal District regions, IOP Conference Series: Materials Science and Engineering 497 (2019) DOI: 10.1088/1757-899X/497/1/012003

14. D. M. Markley, D. L. Barkley, R. D. Lamie, Case Studies of E-Commerce Activity In Rural And Small Town Businesses (Clemson University, 2007)

15. S.D. Zapata, O. Isengildina, C. Carpio, D. Lamie, Do Internet-based Promotion Efforts Work? Evaluating Market Maker, Journal of Agribusiness 29, 159-80, 1 (2011)

16. M. Yu. Fedorova, I. Aleksandrov, Digital economy and green economy: rural unemployment and territorial self-development in Russia, E3S Web of Conferences 110, 2 (2019) 